\title{
DEVELOPMENT OF THE PEACH FIRMNESS DURING HARVEST PERIOD
}

\author{
L. Severa
}

\author{
Received: April 3, 2008
}

\begin{abstract}
SEVERA, L.: Development of the peach firmness during harvest period. Acta univ. agric. et silvic. Mendel. Brun., 2008, LVI, No. 4, pp. 169-176

The objective of the present study is to characterize the rheological properties of peaches according to the results of puncture test force/displacement curves. The measurements were carried out on the universal testing machine. The firmness of the peaches was measured on the equatorial side of the fruit. Four measurements were carried out on each fruit by varying the orientation at intervals by about $90^{\circ}$. The used approach computed six texture parameters from the curves, which were supposed to be representative of skin hardness, fruit deformation before skin rupture, flesh firmness and mechanical work needed to penetrate the fruit. The data were fitted by an exponential function. The correlation is not statistically significant. Its value only support the hypothesis about decrease of the skin strength and other values. Generally, there is a decreases with time from the harvest beginning but the scatter of the data is too high. The results show that used method enables to describe the peach firmness development during the harvest period but the effective use of this method is based on the large number of experiments which are destructive in their nature. Some new approach is briefly outlined.
\end{abstract}

peach, firmness, puncture test

The quality of peach fruit is determined by several internal and external factors. External factors such as shape, mass and color can be measured easily, but internal attributes such as firmness, sugar and acid content and the absence or presence of internal defects are difficult to assess. Firmness is an important internal quality attribute, which changes considerably during ripening and storage. Firmness is an important parameter of fruit quality. Operators on U.S. and European markets often require thresholds values of firmness making it possible to grade the fruits according to their maturity. Firmness depends on different characteristics of fruit cells or tissue turgidity, cell size, wall composition and integrity. Sensory analyses are the best method to estimate all these parameters and to take into account simultaneously the effects of all involved cellular components. However, sensory analyses are difficult to apply on large series of samples. For this reason, physical measurements based on rheological properties of tissues have been used for a long time to evaluate texture.

The most common method for assessing apple fruit firmness is the puncture test. With this test the maximal penetration force is measured that is required to let a cylindrical probe penetrate in the apple flesh up to a predetermined depth. It is often performed manually (Duprat et al., 1995; Johnston et al., 2001; Harker et al., 2002; Hoehn et al., 2003). Sophisticated devices allow a motorized penetration of the probe into the fruit, at a defined speed and the record of the complete force versus displacement curve. These devices were originally developed for apples and pears, but they have also been used for peaches, nectarines, kiwifruits and various other firm fruits. They are less satisfactory for softer fruit such as tomatoes and strawberries. Several authors propose to extract various texture parameters from the forcedeformation curves (Duprat et al., 2000; Mehinagic et al., 2003). Chen et al. (1995) and Duprat et al. (2000) tried to summarize the texture parameters with a small set of numerical values calculated from the penetrometric curve. In these studies, the authors considered the entire force - displacement curve as an indicator of both flesh and skin properties. Wu and Abbott (2002) carried out a mathematical analysis of the penetrometric curves for characterizing 
fruit variability and built a mathematical model representing the relaxation forces as a logarithmic function. In this way, they obtained a high correlation between firmness and the relaxation force at specific relaxation time. This result predicted skin hardness of fruit from penetrometric measurements.

The next development of the penetrometric method of the fruit firmness evaluation needs some other data on relationship between the penetrometric data and some textural characteristics of the fruits. The present paper is focused on the study of the peach firmness at different days of their harvesting.

\section{MATAERIAL AND METHODS}

The peaches (Red heaven) were obtained from the orchards of the Department of Postharwest technologies, Lednice, Mendel University of Agriculture and Forestry. Fruit were picked at the different days during July 2007.

The measurements were carried out on a Universal Testing Machine TIRA TEST. Crosshead speed was $0.00032 \mathrm{~m} / \mathrm{s}(20 \mathrm{~mm} / \mathrm{min})$. The firmness of the fruit was evaluated by using a penetrometer with a $11 \mathrm{~mm}$ plunger. A $1000 \mathrm{~N}$ load cell was used for firmness determinations. The firmness of the peaches was measured on the equatorial side of the fruit. Four measurements were carried out on each fruit by varying the orientation at intervals by about $90^{\circ}$. Six numerical values called texture parameters can be computed from the force/displacement curve (Fig. 1). The maximal force $\left(F_{s}\right)$ represents the force required to puncture the skin. $F_{s}$ represents the skin strength. The probe displacement $\left(D_{b}\right)$, expressed in mm, indicates the probe position at $F_{s}$. It allows the calculation of fruit deformation before the skin rupture. Stiffness (Stif), defined by $\left[F_{s} / D_{b}\right]$, is the slope of the first part of the curve measured from the beginning of the acquisition until $F_{s}$ is reached. Work $l(W 1)$ is the mechanical work needed to reach the rupture point, estimated by the area under the curve up to the skin rupture point. The flesh firmness $\left(F_{f}\right)$ is the average values of the forces measured after the skin rupture. In a similar way, work $2(W 2)$ is the work measured after the skin rupture.

\section{EXPERIMENTAL RESULTS AND DISCUSSION}

In the Fig. 2 the experimental records of the force displacement for peaches harvested on the different days are shown. One can conclude that there is a certain similarity with the schematic in the Fig. 1.

In the Table I the values of the quantities $F_{s}, F_{f}, D_{p}$, and $W l$ are given.

There is a scatter of data. During the same day of the harvesting peaches exhibit a very different firmness. The scatter of the data is shown in the Fig. 3 where the skin strength $F_{s}$ is plotted.

The data exhibit a decrease with the number of days from the beginning of the harvest $(t)$ as shown in Fig. 4.

The data were fitted by an exponential function. The correlation is far to be excellent. Its value only support the hypothesis about decrease of the skin strength with the time from the beginning of the harvest. The probe depth $D_{p}$ seems be nearly independent on the term of harvesting as shown in the Fig. 5.

Owing to this fact the stiffness exhibit the same behaviour as the skin strength - see Fig. 6.

The flash firmness $F_{f}$ does not show any reasonable dependence on the time from the beginning of harvest - see Fig. 7.

Generally, there is a decreases with time from the harvest beginning but the scatter of the data is too high.

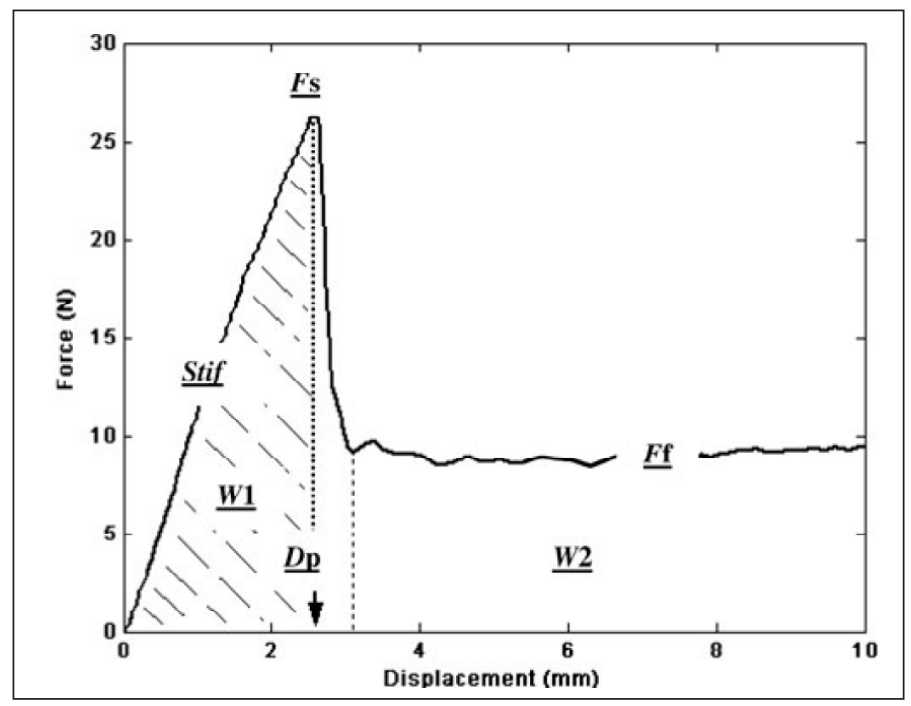

1: Penetrometric force-displacement curve and parameters extracted. $F$ (skin strength), Stif (stiffness), WI (work 1), $D_{p}$ (displacement), $F_{f}$ (flesh firmness) and W2 (work 2) (redesigned picture from Duprat et al., 2000) 


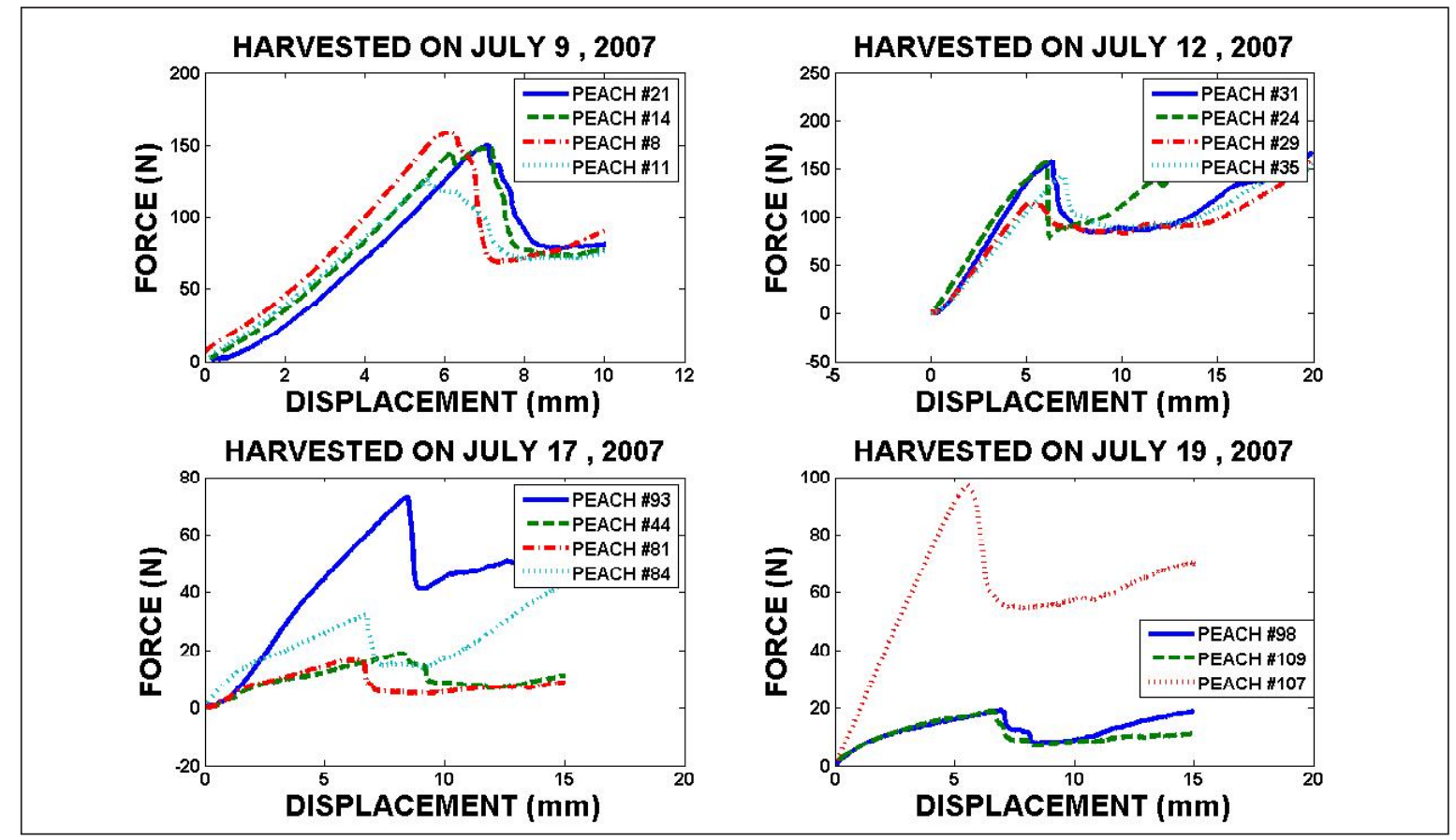

2: The dependence of the force on the probe displacement

I: The results of the firmness measurements

\begin{tabular}{|c|c|c|c|c|c|}
\hline \multirow{5}{*}{9.7 .2007} & Peach \# & 21 & 14 & 8 & 11 \\
\hline & $F_{s}(\mathrm{~N})$ & 150.68 & 150.85 & 160.24 & 143.7 \\
\hline & $D_{p}(\mathrm{~mm})$ & 7.11 & 6.21 & 6.16 & 5.59 \\
\hline & $F_{f}(\mathrm{~N})$ & 80 & 75.7 & 73.8 & 89.3 \\
\hline & Wl (Nmm) & 1210 & 1034 & 1082 & 873 \\
\hline \multirow{5}{*}{ 12.7.2007 } & Peach \# & 31 & 24 & 29 & 35 \\
\hline & $F_{s}(\mathrm{~N})$ & 159.45 & 156.35 & 114.84 & 141.81 \\
\hline & $D_{p}(\mathrm{~mm})$ & 6.35 & 6.07 & 5.24 & 6.97 \\
\hline & $F_{f}(\mathrm{~N})$ & 85 & & 85 & 88 \\
\hline & Wl (Nmm) & 1274 & 1132 & 635 & 1042 \\
\hline \multirow{5}{*}{ 17. 7.2007} & Peach \# & 93 & 44 & 81 & 84 \\
\hline & $F_{s}(\mathrm{~N})$ & 16.34 & 18.9 & 72.86 & 32.05 \\
\hline & $D_{p}(\mathrm{~mm})$ & 6.37 & 8.31 & 8.46 & 6.75 \\
\hline & $F_{f}(\mathrm{~N})$ & 5 & 7.72 & 44 & 15 \\
\hline & $\mathrm{Wl}(\mathrm{Nmm})$ & 132 & 184 & 723 & 238 \\
\hline \multirow{5}{*}{ 19.7.2007 } & Peach \# & 98 & 109 & 107 & \\
\hline & $F_{s}(\mathrm{~N})$ & 19.11 & 18.37 & 93.5 & \\
\hline & $D_{p}(\mathrm{~mm})$ & 7.13 & 6.63 & 5.7 & \\
\hline & $F_{f}(\mathrm{~N})$ & 8 & 8 & 54 & \\
\hline & Wl (Nmm) & 176 & 153 & 567 & \\
\hline \multirow{5}{*}{ 24.7.2007 } & Peach \# & 138 & 132 & & \\
\hline & $F_{s}(\mathrm{~N})$ & 106.25 & 8.12 & & \\
\hline & $D_{p}(\mathrm{~mm})$ & 6.86 & 5.72 & & \\
\hline & $F_{f}(\mathrm{~N})$ & 62 & 2.5 & & \\
\hline & Wl (Nmm) & 753 & 72 & & \\
\hline
\end{tabular}




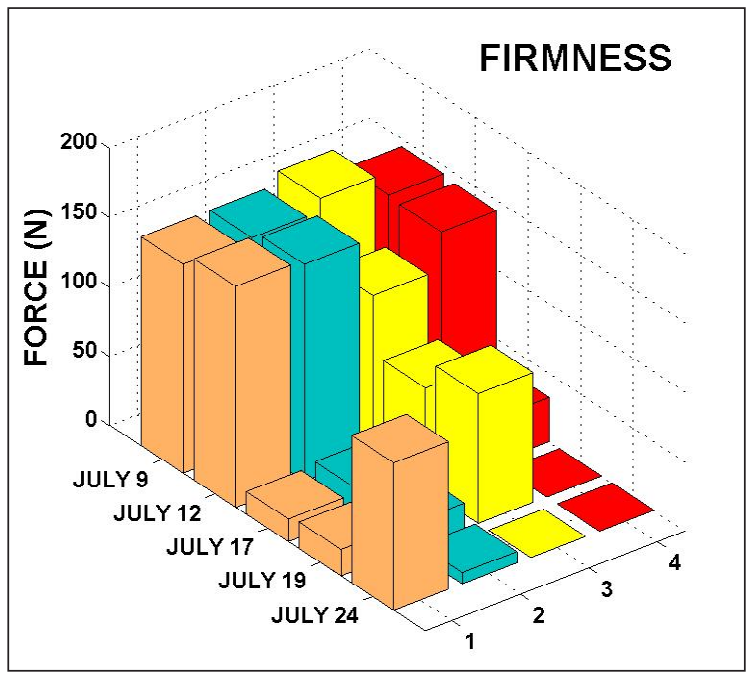

3: The skin strength of the single peaches harvested at the different days

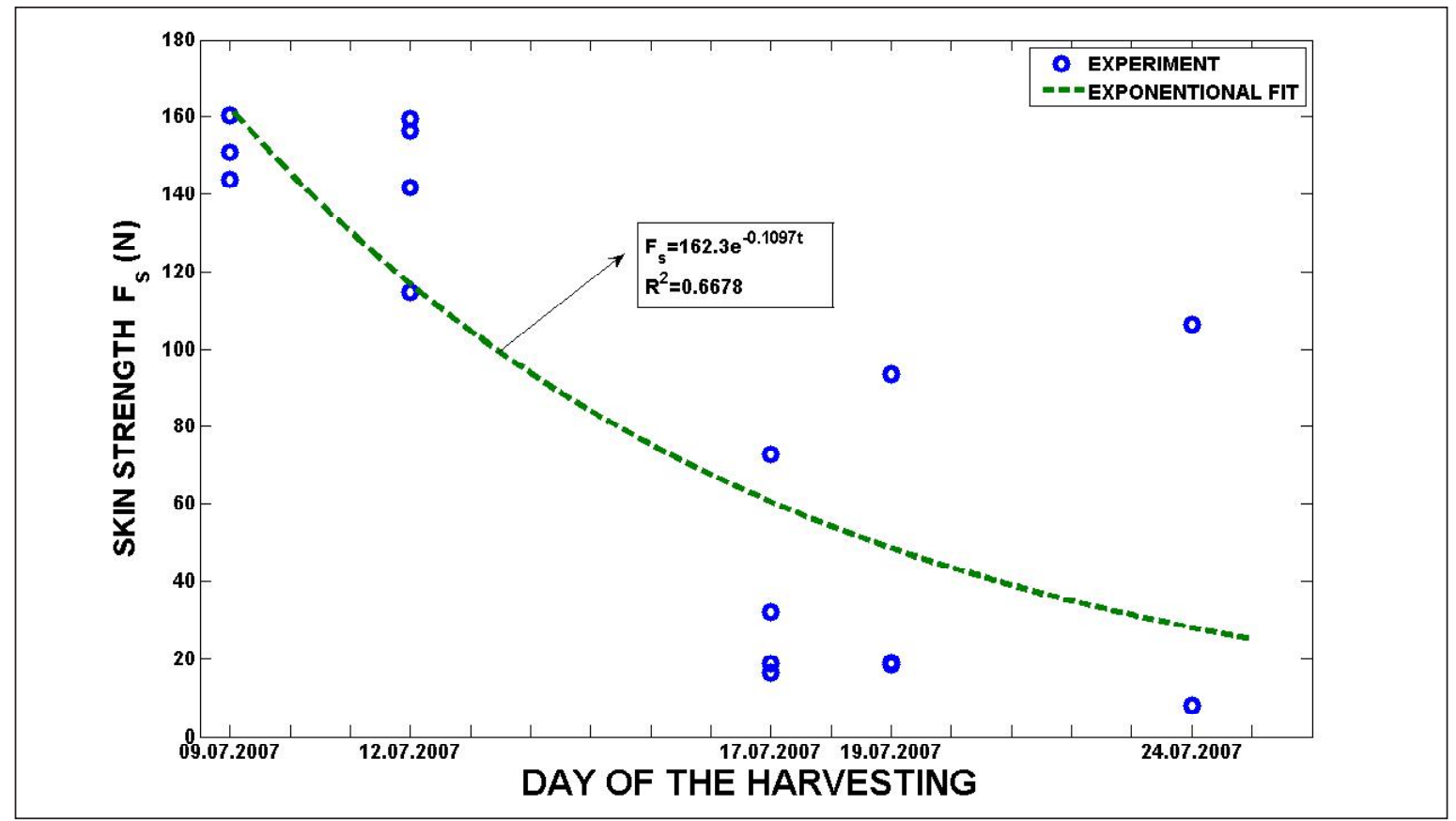

4: The dependence of the skin strength on the number of days after the beginning of harvesting

\section{SUMMARY}

The findings obtained in given paper show the significant influence of fruit variability on experimental results. The measurement of the whole load - deformation curves enables to evaluate different areas of the peach resistance to a cylindrical probe penetration. The skin strength exhibits a tendency to decrease with the time of the harvesting. At the same time the depth of the penetration at the moment of the skin fracture is nearly independent on the time mentioned above. The same conclusion is valid for the flesh firmness. The extent of fruit to fruit variability introduces an additional consideration into deciding which method to use. It is important to ensure that sufficient measurements are made to ensure full characterization of a population of peach fruit. It is perhaps better to have a less accurate measurement on a greater number of fruit than an extremely accurate measurement on one or two pieces of fruit. Owing to the destructive character of the puncture test the development of a new method seems be urgently needed. One of the perspective methods is based on the measurement of the acoustic properites of the fruits. The use of this non-destructive firmness measure- 


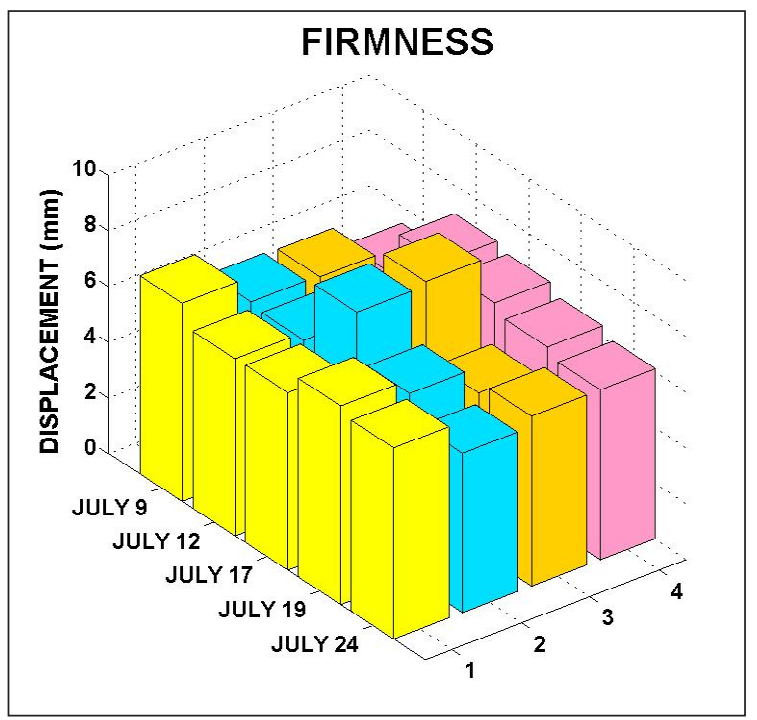

5: The probe displacement $D_{p}$

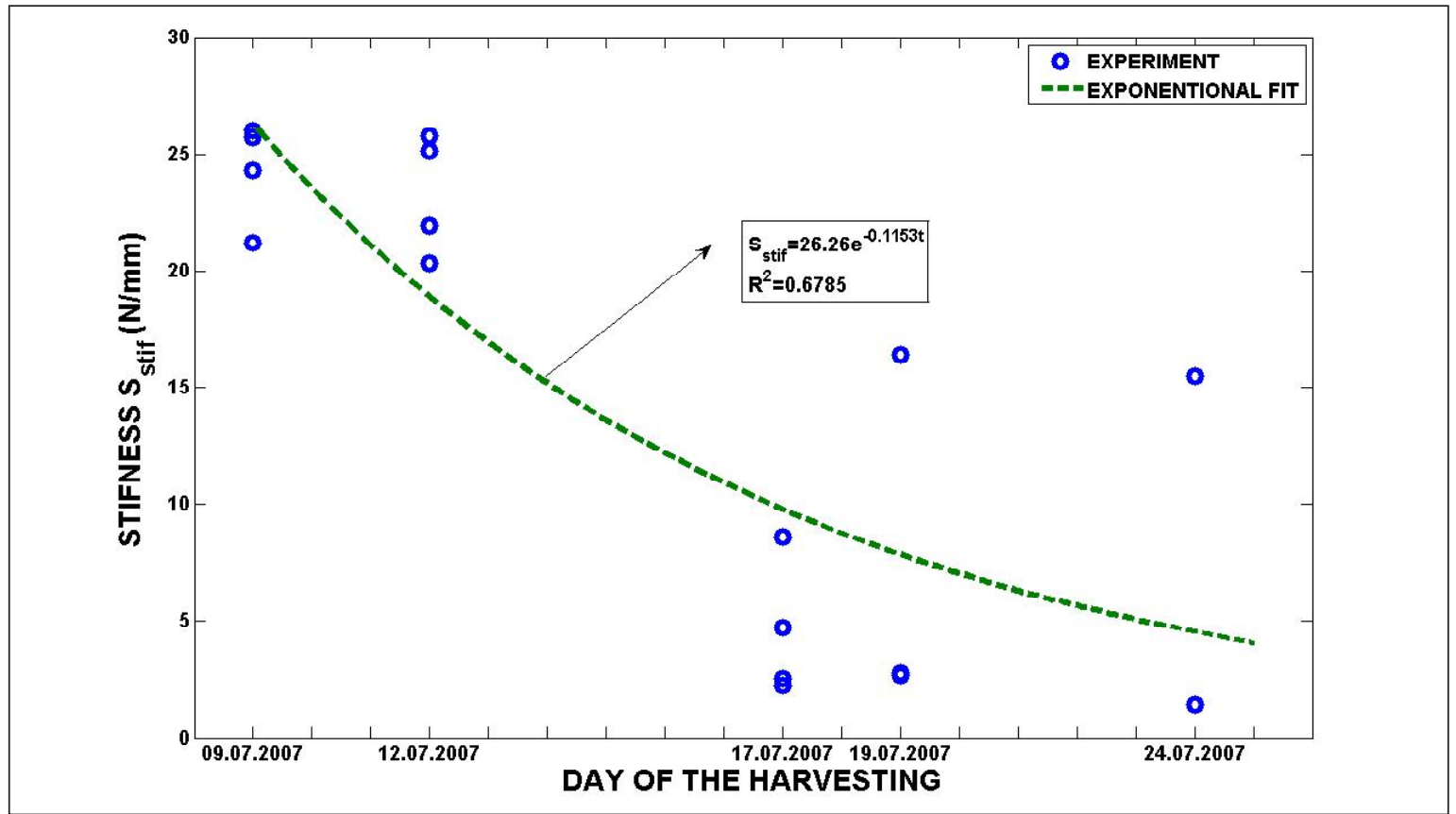

6: Skin strength at the different days of harvest

ments, based on elastic tissue properties rather than tissue failure properties, is becoming available for several industries (Chen and Tjan, 1998; Abbott, 1999; De Ketelaere et al., 2006). The availability of new technology that allows automated nondestructive firmness measurements will allow greater sampling, reducing variability in firmness measurements of bulk lots, and will help to segregate fruit highly susceptible to bruising or fruit with a similar ripening stage from the sample. In addition, the reduction of fruit sample variability commonly associated with destructive measures will improve our research programs. In order to verify the reliability of non-destructive methods the attention should be focused on the direct relationship between non-destructive measurements and relevant fruit texture changes during ripening. This research will be subject of our forthcomming paper. 


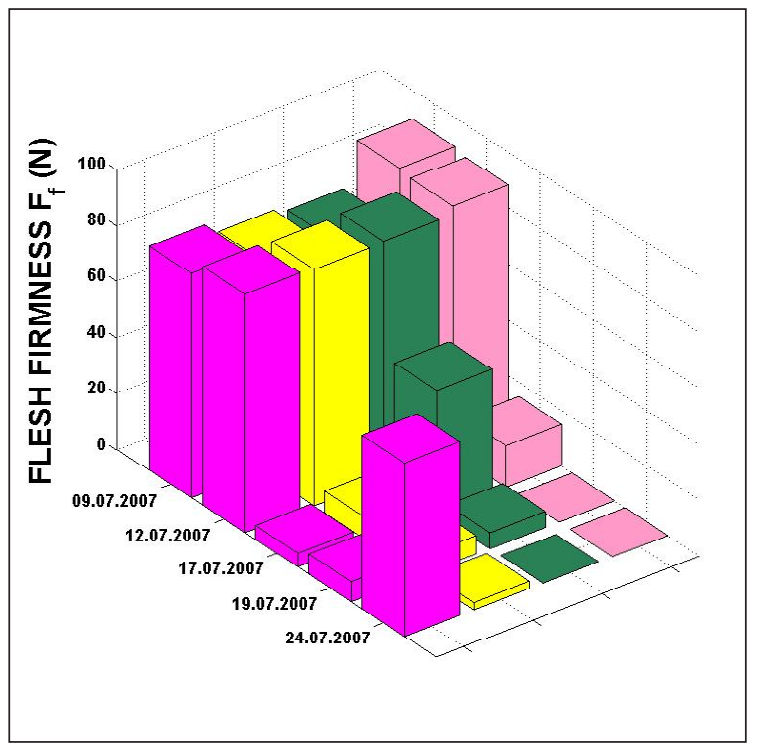

7: The development of the flesh firmness with the peaches maturity

\section{SOUHRN}

Vývoj pevnosti broskví během období sklizně

V práci je sledována závislost deformačních charakteristik broskví (Red Haven) na datu jejich sklizně. Deformační charakteristiky jsou stanoveny pomocí měření závislosti síla - hloubka penetrace válce o průměru 11 mm. Ukazuje se, že na této křivce je možné rozlišit různá stadia deformačního odporu daného ovoce. Proces deformace je popsán šesti veličinami (pevnost slupky, hloubka penetrace v okamžiku lomu slupky, tuhost, práce potřebná pro porušení slupky, pevnost dužniny a práce potř̌ebná pro deformaci dužniny). Přestože dané veličiny vykazují tendenci k poklesu s termínem sklizně, pozorujeme značný rozptyl měřených hodnot. Tento rozptyl nelze eliminovat ani poměrně pečlivým výběrem sklízených broskví. Ukázalo se, že pro hodnocení pevnosti broskví je vhodněǰši spíše jednodušší metoda (např. klasický Taylor-Magnusův test), která stanoví jednu veličinu a která umožňuje snadné testování velkého množství vzorkủ, než exaktnější metoda umožňující získat velice podrobné informace pro několik málo vzorkủ ovoce. S ohledem na destruktivní charakter dané penetrační metody tak bude vhodné testovat jiné, nedestruktivní metody, např. metody akustické. Tento směr bude sledován v dalších pracích.

broskev, pevnost, penetrační test

\section{ACKNOWLEDGEMENTS}

The research has been supported by the Grant Agency of the Czech Academy of Sciences under Contract No. IAA201990701

\section{REFERENCES}

ABBOTT, J. A., 1999: Quality measurement of fruits and vegetables. Postharv. Biol. Technol. 15, 207-225

CHEN, H., DUPRAT, F., GROTTE, M., LOONIS, D. and PIETRI, E., 1995: Relationship of impact transmission wave to apple texture during ripening. J. Texture Studies 27, 123-141.

CHEN, P., TJAN, Y., 1998: A real-time impact sensing system for online firmness sensing. In: Proceedings of the Ag. Eng. Conference, Oslo, Paper 98-F-006
DE KETELAERE, B., HOWARTH, M. S., CREZEE, L., LAMMERTYN, J., VIAENE, K., BULENS, I., DE BAERDEMAEKER, J., 2006: Postharvest firmness changes as measured by acoustic and low-mass impact devices: a comparison of techniques. Postharv. Biol. Technol. 4l, 275-284

DUPRAT, F., GROTTE, M. G., PIETRI, E. and STUDMAN, C. J., 1995: A multi-purpose firmness tester for fruits and vegetables. Comput. Electron. Agr. 12, 211-223

HARKER, F. R., MAINDONALD, J., MURRAY, S. H., GUNSON, F. A., HALLET, I. C. and WALKER, S. B., 2002: Sensory interpretation of instrumental 
measurements 1: Texture of apple fruit. Postharvest Biol. Technol. 24, 225-239

HOEHN, E., GASSER, F., GUGGENBÜHL, B. and KÜNSCH, U., 2003: Efficacy of instrumental measurements for determination of minimum requirements of firmness, soluble solids, and acidity of several apple cultivars in comparison to consumer expectations. Postharvest Biol. Technol. 27, 27-37

JOHNSTON, J.W., HEWET, E. W., BANKS, N. H., HARKER, F. R. and HERTOG, M., 2001: Physical change in apple texture with fruit temperature: Ef- fects of cultivars and time of storage. Postharvest Biol. Technol. 23, 13-21

MEHINAGIC, E., ROYER, G., BERTRAND, D., SYMONEAUX, R., LAURENS, F. and JOURJON, F., 2003: Relationship between sensory analysis, penetrometry and visible-NIR spectroscopy of apples belonging to different cultivars. Food Qual. Prefer. 14, 473-484

WU, T. and ABBOTT, J. A., 2002: Firmness and force relaxation characteristics of tomatoes stored intact or as slices. Postharvest Biol. Technol. 24, 59-68

\section{Address}

Ing. Libor Severa, Ph.D., Ústav techniky a automobilové dopravy, Mendelova zemědělská a lesnická univerzita v Brně, Zemědělská 1, 61300 Brno, Česká republika, e-mail: severa@mendelu.cz 
